\title{
Electronic document management and electronic cases in Russian arbitration courts: advantages and development prospects
}

\author{
Tatiana Korobeinikova* \\ Far-East Institute of Management, Branch of RANEPA, 680000 Khabarovsk, Russia
}

\begin{abstract}
An analysis of the activities of arbitration courts demonstrates the effectiveness of the implementation of electronic justice in Russia, which ensures the promptness of procedural actions by the parties to the dispute. Statistics show a constant increase in the number of lawsuits filed with the courts. The current procedural legislation provides for the possibility of filing a lawsuit in court in an electronic form. Meanwhile the bulk of appeals is carried out in the usual manner in a paper form, which entails certain problems, for example, an increase in the workload on the staff of the court apparatus, the need to form court cases in a paper form, and difficulties in storage.The author proposes to establish in the law a rule providing for filing a claim in an electronic form as the main method, and going to court by filing in a standard paper form - as an exception. The implementation of this proposal will make it possible to switch to the formation of completely electronic court cases, which fully meets modern requirements. At the same time the author points to the possibility of endowing multifunctional centers for the provision of state and municipal services with the right to file lawsuits and other documents to the courts in an electronic form. This will shorten the time for consideration of cases, as well as reduce the costs of both the courts and the participants in the trial.
\end{abstract}

\section{Introduction}

The most widespread and effective use of digital technologies is demonstrated by the arbitration courts of the Russian Federation. Case materials, including judicial acts, are placed in the Card file of Arbitration Cases (CAD) and the parties can submit documents through the "My Arbitrator" system, also there is an opportunity to remotely familiarize themselves with the case materials.

During their existence and applying online services have managed to demonstrate the merits of the transition of courts to the electronic sphere. For example, filing a document electronically through "My Arbitrator" allows the court to review it on the day or the next day after sending, which would not have been possible if sent by the postal service. Likewise, the parties do not wait for a judicial act sent by mail but can receive it almost immediately after the court has delivered it to the Card file of Arbitration Cases.

\footnotetext{
* Corresponding author: korts@ rambler.ru
} 


\section{Materials and methods}

The material of the research was the existing works of both Russian and foreign scientists. The methodological basis of the research was formed by the method of materialistic dialectics, the systemic method, the method of comparative jurisprudence.

\section{Results}

Electronic filing of documents along with the possibilities provided by the CAD (card file of arbitration cases) allow the parties to perform a number of procedural actions remotely without visiting the court, which can reduce court expenses. This favourably affects the effectiveness of the actions of the process participants, since they become independent of the schedule of a particular court.

Working with documents in an electronic format is convenient for both judges and the court apparatus, since procedural documents submitted in an electronic form simplify the procedure for their registration and preparation for attachment to the materials of the court case, as its scanning and additional placement is not required. Only a part of the documents (for example, a claim, a lawsuit, a petition) is sent to the materials of the case in a printed form, and numerous attachments are stored in the Card File. This makes it possible to form a case in a smaller volume which simplifies the process of familiarization, registration, storage and referral of the case (for example when appealing) to another court.

In this regard, the filing of documents in an electronic form seems to become the major court handling.

To implement this initiative it is necessary to amend the procedural legislation, securing the relevant requirements. At the same time, it is necessary to provide for the procedure of filing and considering a petition motivating the application of a lawsuit (claim, petition, revocation, etc.) on paper.

Meanwhile, the widespread use of modern technologies aimed at optimizing the judicial process should not negatively affect citizens (organizations), deprived of an objective opportunity to comply with the requirement to submit a document in an electronic form. For this purpose, it is proposed to provide in the law a procedure for filing a lawsuit in an electronic form through multifunctional centres (MFC), which render a wide range of state and municipal services.

\section{Discussion}

The federal target program "Development of the judicial system of Russia for 2013 - 2020" provides for the creation of mobile justice, electronic justice, the introduction of software for analytical support of activities, scanning of all documents submitted to the courts, as well as the formation of electronic files and an electronic archive of court cases. [1] The implementation of this program demonstrates an increase in the number of courts using the possibility of electronic interaction with citizens and legal entities. (fig. 1) [1] 


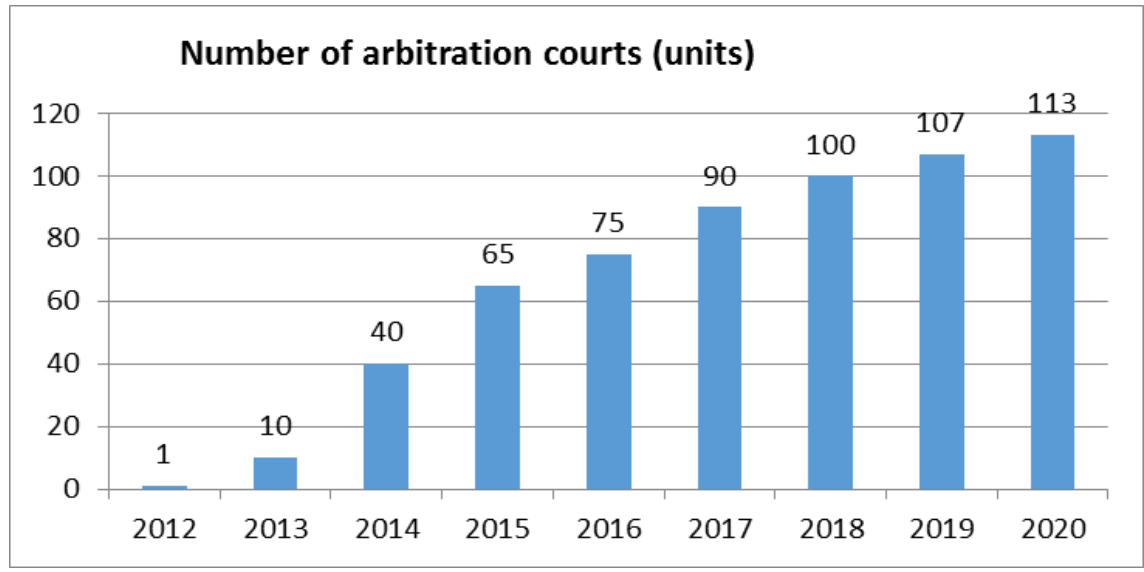

Fig. 1. The number of arbitration courts (units) using electronic interaction with citizens and legal entities

According to the data posted on the website of the Judicial Department under the Supreme Court of the Russian Federation, there is a constant increase in the number of lawsuits and claims filed with arbitration courts (fig. 2). [2]

\section{Number of lawsuits submitted to arbitration courts (in thousands)}

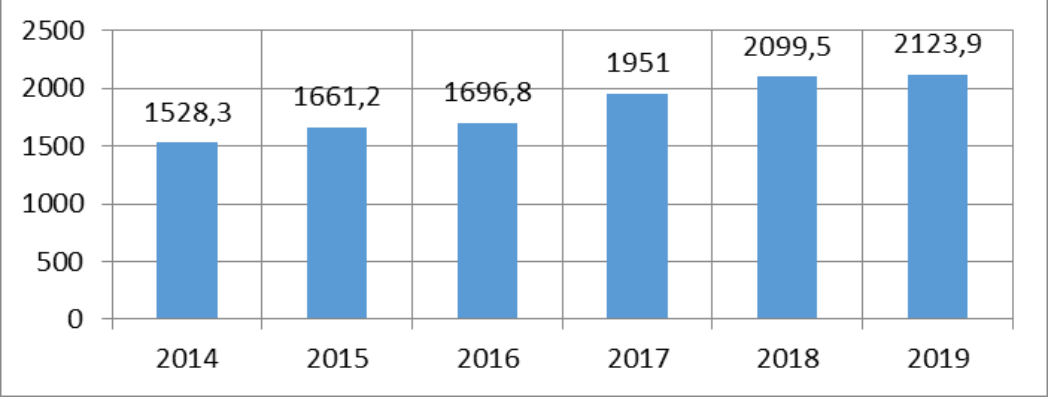

Fig. 2. Number of lawsuits filed with arbitration courts (in thousands).

"E-justice" system provides the ability to perform actions related to the submission of documents to the court, handling and movement of documents in court, the publication of judicial decisions and information on the progress of the case, informing trial participants of all events in the case, etc. [3]

As a rule, in legal science three components of electronic justice are distinguished: conducting an electronic case, filing documents electronically to the court and publishing information about court cases via the Internet, including adopted judicial acts [4].

As O.V. Nikolaychenko rightly notes, a person's appeal to the judicial authorities by means of an electronic document creates the preconditions for a thorough study by a judge and for a decision on the possibility of accepting the case for court proceedings. [5] Requests in an electronic form are submitted to the courts by filling out the form posted on the official websites of the courts in the Internet, in accordance with the procedure for submitting documents in an electronic form. [6]

Despite the advantages of the e-justice system [7], still the preferred form is the filing of documents in a paper form - by courier or by mail. This state of affairs creates a number of problems both for the court and for the participants in the process. 
Acceptance of the lawsuit entails the formation of a court case. The provisions of the current legislation as well as the instructions for office work in arbitration courts provide for the parallel management of an electronic file and a court case in a traditional (paper) form. Subject to strict requirements for office work, a number of mandatory actions are taken in relation to written explanations, reviews and additional evidence: registration, scanning, placement in the CAD, firmware, inventory. This affects the increase in the workload of the assistant judge and the secretary (specialist) of the judicial composition.

After the adoption of the judicial act the court cases are placed for storage to the archive of the court. As a rule, the archive is often full; the area of the premises used for these purposes does not increase. But even greater difficulties arise when considering cases of special production, for example, bankrupt ones. Bankruptcy procedures are sometimes delayed for several years. The number of volumes on bankruptcy cases (main and isolated disputes) can amount to several dozen (for example, case No. A73-14561 / 2008 - more than 50 volumes of the main case, case No. A73-8059 / 2015 - more than 30 volumes).

When appealing against judicial acts of arbitration courts, multivolume cases along with complaints are sent by post as a rule to other constituent entities of the Russian Federation. On appeal a judicial act in an appellate court the case is sent and returned to the court of first instance twice, and on subsequent appeal the number of transfers reaches four.

It seems that the above problems can be solved by introducing amendments to the procedural legislation, which will ensure a gradual transition to electronic filing of documents, leaving them in printed (paper) form only in special circumstances.

The experience of foreign countries demonstrates the reality and effectiveness of this approach. Australia's e-court strategy includes in particular filing of documents to the court in an electronic form; communication and exchange of documents in electronic form between the court and the process participants, between the parties in the trial; electronic data storage; ensuring the availability of judicial acts in civil cases for the general public [8]; access to relevant documents, for example, to a copy of the transcript of the court session [9]. In England, the courts recommend the parties to file procedural documents to use the electronic form on a specialized portal, which provides the receipt of documents 24 hours a day. [10] In Germany courts use electronic. [11] Today a country with a high rate of applying e-justice is Singapore, where all the necessary services exist that ensure the conduct of electronic cases. [12]

As already noted, today it is possible to file documents electronically to any arbitration court through My Arbitrator. At the same time the advantage of this service is its relation with the State Services portal through which authorization in the system passes. By the end of 2020, 126 million people were registered on the Internet portal of public services [13] (in 2019 - 103 million, in 2018 - 85 million people [14]).

Of course, in the context of the establishment of electronic justice, such an innovation cannot occur abruptly and simultaneously cover all the courts that are part of the judicial system of the Russian Federation. To make demands on citizens and organizations in terms of the form of filing lawsuits (claims), the courts themselves must be ready to use all the possibilities of electronic justice provided by procedural legislation. We must agree with the opinion of the authors that "... maintaining electronic document management requires certain user skills for judges and court staff, the availability of appropriate software and the material and technical base of the courts." [15]

When amending procedural legislation in terms of requirements to the form of a lawsuit (claim, petition and other filed documents), it is necessary to maintain a balance between the interests of the court as an organization that needs to optimize its activities, and participants in the process in terms of observing their right to access to justice. To achieve this goal, it is proposed to include in the list of public services provided by multifunctional centers 
(hereinafter - MFC, My Documents) - the submission of documents in an electronic form with the court.

Today there are more than 13,000 MFC offices in the Russian Federation with the ability to assist in receiving state and municipal services for $96 \%$ of the country's population.

Thus, persons who for some reason do not have the opportunity to use My Arbitrator service by themselves can contact the MFC with a lawsuit (another document), where an electronic form of documents will be created and the documents will be sent to the court indicated by the applicant. In this case the applicant's personality will be confirmed by identifying his personality by an employee of the MFC. The proposed procedure will not only ensure the receipt of documents in the court in an electronic form, which immediately become part of the electronic file (without the need to scan and place them in a specialized system), but also reduce the time for receiving correspondence excluding the time for the "mail run".

Financing the activities of multifunctional centers in this part will be possible at the expense of budgetary funds, that are now paid to organizations rendering arbitration courts with services for scanning incoming documents within the framework of the concluded state contract.

It is necessary to foresee that a citizen (organization) in a settlement where there is no multifunctional center as well as a professional representative, can file a lawsuit (another document) in the traditional form by sending it by the postal service with a motivated application. Accordingly, when resolving the issue of accepting such a lawsuit for proceedings (on attaching a document to the case), the specified petition will be initially considered by the court (by analogy with the petition for a deferral (installments) for the payment of the state fee, for the restoration of the procedural period). An exception will also be the presentation at the request of the court of original documents that are returned to the party.

The implementation of this proposal will allow a citizen (organization) who does not have an objective opportunity to convert by himself documents into an electronic form and file them to court, to exercise their right to judicial protection. As a consequence, this will allow realizing the concept of getting closer to citizens. [16] User orientation, his satisfaction with the e-justice system should be the main criterion for evaluating this system. [17]

\section{Conclusion}

The use of a document in electronic form is convenient for both the judge and the participants in the process. First, the workload on court staff decreases significantly. Secondly, when filing documents electronically a party can familiarize itself with the case materials online. In addition, the formation of an electronic file contributes to the faster formation of such cases, operational movement when appealing a judicial act, simplifies a following storage.

The proposal on the possibility of court appeal by filing documents in an electronic form (as the main method) through the MFC is aimed at optimizing the activities of employees of the court apparatus. Full displaying of documents in an electronic form allows to reduce the volume of a court case filed in a traditional paper form. Thus, instead of "multivolume" books, a pair of volumes of the court case will be formed, containing only the main petitions and procedural documents, and all appendices will be available in an electronic form.

\section{References}


1. Decree of the Government of the Russian Federation of December 27, 2012, N 1406 "On the federal target program" Development of the judicial system of Russia for 2013 - 2024 ", Collected Legislation of the Russian Federation, 1, Article 13 (2013)
2. Judicial statistics (2020).

URL. https://www.cdep.ru/userimages/sudebnaya_statistika/2020/Obzor_sudebnoy_statistiki _o_deyatelnosti_federalnih_arbitragnih_sudov_v_2019_godu.pdf

3. Yu. A. Kantser, Electronic Justice in an Arbitration Procedure: New Challenges and Adaptation of Judicial Proceedings, Arbitration and civil procedure, 2, 36-40 (2021), DOI: 10.18572 / 1812-383X-2021-2-36-40

4. S.V. Romanenkova, Arbitration and civil procedure 4, 26 (2013)

5. O.V. Nikolaychenko, Court Administrator 2, 34 (2019)

6. Order of the Judicial Department under the Supreme Court of the Russian Federation of December 28, 2016 N 252 "On Approval of the Procedure for Submitting Documents to Arbitration Courts of the Russian Federation in Electronic Form, Including in the Form of an Electronic Document", Bulletin of Acts on the Judicial System, 2 (2017)

7. T.S. Korobeinikova, European Publisher. EpSBS 103, 143 (2021). DOI: https://doi.org/10.15405/epsbs.2021.03.19

8. V.I. Reshetnyak, Russian Juridical Journal 3, (2016)

9. Yu.V. Murom, Innovative Science 4, 137 (2019)

10. T. de la Fosse, J. Popple, Escaping the Relational Database Paradigm: Case Management in the High Court of Australia, Technology for Justice Conference Presentation, Melbourne (1998)

11. L. Lepore, S. Pisano, F. Alvino, F. Paolone, Lecture Notes in Information Systems and Organization 27, 49 (2019). DOI: 10.1007/978-3-319-90500-6_5

12. I.A. Aleshkova, O.H. Molokaeva, Judicial power in circumstances of new information reality, State and law in a new information reality. 83 (2018), DOI: 10.31249 / pras / 2018.01.0513.2020 On State Services: new users, payments and export flights. URL. https://www.gosuslugi.ru/help/news/2020_12_30_results_of_the_year

13. What Government Services did for you in 2018. URL. https://www.gosuslugi.ru/help/news/2018_12_28_Report_2018

14. D.K. Valeev, E.V. Bazilevskikh, E-justice "regulatory system, Russian Justice 8, 34 (2019)

15. J. Cano, C.E. Jimenez, R. Hernandez, S. Ros, New tools for e-Justice: legal research available to any citizen, Second international conference on edemocracy \& egovernment (ICEDEG), 108 (2015)

16. O. Oktal, O. Alpu, B. Yazici, Aslib journal of information management 68(6), 716 (2016). DOI : 10.1108 / AJIM-04-2016-0048. 